\title{
THE ISSUES OF SUSTAINABLE ECONOMIC GROWTH
}

\author{
Ulugbek Azizov ${ }^{1}$
}

\begin{abstract}
This article discusses the importance of economic growth. The study analyzes several criteria influencing the economic growth of Uzbekistan, and describes the scientific conception and options of components relating to classic economic theory. This research reveals the conceptual basis for economic growth in Uzbekistan by means of varying instruments, and recommends mechanisms to improve the country's economy. In particular, monetary policy and fiscal policy approaches are highly effective in maximizing the economic growth rate and reaching positive positions in both internal and external balances. Therefore, monetary and fiscal policies are a high-priority issue for policy makers and the government. This is especially topical for the policy makers of Uzbekistan, which in 1991 - after proclaiming independence, adopted an evolutionary reform strategy and began a gradual transformation from a Centrally Planned Economy to a Socially Orientated Market Economy.
\end{abstract}

UDC Classification: 338.1, DOI: http://dx.doi.org/10.12955/cbup.v3.602

Keywords: economic growth, monetary instrument, fiscal instrument, FB, BOP

\section{Introduction}

The highest priority for any country is to achieve and maintain stable economic growth at an optimal level. The growth of the economy is one of the most important indicators showing the power and welfare of a country. A favorable economic position depends on positive influences of the federal bank (FB) and the external balance of payments (BOP), along with a high national economic growth rate from implementing a reasonable macroeconomic policy. In particular, monetary policy and fiscal policy approaches are highly effective in maximizing the economic growth rate and reaching positive positions in both internal and external balances. Therefore, monetary and fiscal policies are a highpriority issue for a country's policy makers and government. This is especially topical for the policy makers of Uzbekistan, which in 1991, after proclaiming independence, adopted an evolutionary reform strategy, and began a gradual transformation from a Centrally Planned Economy to a Socially Orientated Market Economy.

Karimov (2013), in considering Uzbekistan among the advanced countries providing sustainable development of economy and improving quality of life, emphasized that, "During the 20 years of independent development of Uzbekistan, GDP (gross domestic product) grew by 3.5 times, while GDP per capita increased 2.5 times. In addition the household income is 3.8 times higher than 20 years ago.”

The dynamics of economic growth primarily depend on the macroeconomic policy of the country. On a macro scale, the growth of the economy enhances people's living conditions and living standards, while economically it raises the quality and quantity of production to a higher standard.

There are many views and arguments among social scientists and policy makers on what principles and parameters should fluctuate with monetary policy and fiscal policy instruments, in order to maximize economic growth.

One such principle is the monetary approach towards achieving external balance. This emphasizes that the BOP, while reflecting real factors such as income, tastes, or factor productivity, is essentially a monetary phenomenon (Appleyard, Field \& Cobb, 2006). This means that the position of BOP mainly depends on the monetary policy. If a country has a BOP deficit, there is an outflow, whereas if a country has a BOP surplus, there is inflow of international reserve assets. The monetary equilibrium provides the basis for this concept. It means that money supply equals money demand or $\mathrm{M}=\mathrm{L}=$

\footnotetext{
${ }^{1}$ Ulugbek Azizov, Tashkent Financial Institute, Republic of Uzbekistan, u.azizov@tfi.uz
} 
$\mathrm{kPY}$ (where $\mathrm{M}=$ money supply, $\mathrm{L}=$ =money demand, $\mathrm{k}$ is the constant embodying of all other variables, $\mathrm{P}=$ price level, $\mathrm{Y}=$ real income or GDP).

This study's main objective is to understand the theory of how macroeconomic policies affect economic growth, and, by analyzing this concept, create an econometric model, and develop recommendations to support the goals of macroeconomic policies.

This research uses statistical methods of correlation and regression, and economic modeling, to identify the association between macroeconomic indicators.

\section{Literature review}

Petty (1679) and later Smith (1776) conveyed the initial ideas about the wealth derived from economic growth. All modern theoretical bases of economic growth is associated with theory of macroeconomic equilibrium of Keynes (1936), later referred to Neo-Keynesian theory, and the theory of neoclassical production.

According to the "Domar Paradox," named after the American economist, Evsey Domar, governments need to increase the level of investments to maintain a stable level of growth and realize the full potential of production (Tojiboeva, 2003). This type of economic growth is referred to as guaranteed economic growth, and allows complete exploitation of capital. A guaranteed economic policy is precarious when connected to the investment policy of government.

Apart from the Neo-Keynesian theory, the neoclassical school takes into account many factors of economic growth. Representatives of the neoclassical school include the American economist Paul Howard Douglas and American mathematician Charles Wiggins Cobb, who together developed the macroeconomic Cobb-Douglas model. This model evaluates the effect of different factors on the growth of manufacturing and national income. Later, the Dutch economist and Nobelist, Jan Tinbergen, further developed the Cobb-Douglas model (Chepurina \& Keseleva, 1998).

In the middle of 1950s, advanced countries of the world strongly competed for science and technology and this triggered unstable economic growth. At this point of time, issues with economic growth captured the attention of both the Neo-Keynesian and the neoclassical schools. As a result, the development of science and technology began to clarify its influence on economic growth.

The American economists, Edmund Phelps, Robert Solow, James Meade, and Edward Fulton Denison also attempted to solve issues of economic growth in relation to advances in technology. For example, Phelps (1996) invented the "golden rule of savings" in his book devoted to researchers in economic growth, and Solow (1956), who was awarded a Nobel prize, wrote of his scientific proof of the golden rule of savings and achieving maximum level of consumption.

The main goal of the Uzbekistan Republic, after gaining independence, was to "bail out" the economy from the crisis and to attain a stable growth rate. For this reason, a wide range of government specialists and scientists accomplished various scientific and practical reforms.

\section{Data and methodology}

Economic growth is an indicator of the increase in a nation's total output of goods and services for a specific period ( 1 year, 5 years, or 10 years) compared with the same period in the past. In modern economic theory and practice, economic growth is the increase (or decline) in GDP produced by an economy over an exact period - fiscal year - relative to the previous one.

Depending on factors and expenses affecting economic growth, the theory of economics divides it into two types: extensive and intensive (Tojiboeva, 2003). Extensive is the heightening of the economic growth through attraction of additional resources, such as labor power, technology, energy, 
natural resources, and the like, whereas intensive is about achieving economic growth by efficient resource management, and better efficiency of production and human resource management.

There are many traditional and untraditional indicators for economic growth. For example, traditional indicators include real growth of GDP, GDP per capita, increase of population's real income or savings, average life span, and social services of medical services, energy, natural gas, and education. In comparison, untraditional indicators are automobile per capita, washing machines per capita, and similar attributes, which rate the provision of objects that are important in daily life.

There are several factors affecting economic growth. In conditions of the economic market, three main factors play important roles in (Y) production of goods and services. These factors constitute labor (L), Capital (K), and soil (natural resources-N). Hence, gross production or gross domestic product can be stated as follows:

$$
Y=f(L, K, N)
$$

This is mathematical model estimates economic growth. A simplified form follows:

$$
\Delta Y=\left(\frac{\Delta Y}{\Delta L}\right) \times L+\left(\frac{\Delta Y}{\Delta K}\right) \times K+\left(\frac{\Delta Y}{\Delta N}\right) \times N
$$

With modern methodology, this changes into the following:

$$
\Delta Y=\left(\frac{\Delta Y}{\Delta C}\right) \times C+\left(\frac{\Delta Y}{\Delta G}\right) \times G+\left(\frac{\Delta Y}{\Delta I}\right) \times I+\left(\frac{\Delta Y}{\Delta X}\right) \times X-\left(\frac{\Delta Y}{\Delta M}\right) \times M
$$

where, $\mathrm{C}=$ consumption, $\mathrm{G}=$ government spending, $\mathrm{I}=$ investment, $\mathrm{X}=$ export, and $\mathrm{M}=$ imports.

Economic growth was always at the center of arguments concerning the economy of a wide range of economic scientists, policy makers, and other specialists, from varying nationalities. A main argument associated with economic growth involved questions that were similar to the following: "What is an objective of economic growth?”, "How should the dynamics of economic growth be?” and "Due to what factors is economic growth achieved?”

In the 1930s, a follower of Keynes, Roy Harrod, developed his dynamic model of economic growth. In the opinion of Harrod (1997), the saving rate, capital capacity, and increase in population need to be equal to achieve economic growth. He proclaimed that growth in population, as well as the progress of technology, is a natural condition for economic growth. Below is the main equation of Harrod's:

$$
G=s / C
$$

where,

$$
\begin{array}{ll}
\mathrm{G}=\Delta \mathrm{Y}_{\mathrm{t}} / \mathrm{Y}_{\mathrm{t}-1} & =\text { level of increase, } \\
\mathrm{C}=\Delta \mathrm{K} / \Delta \mathrm{Y}_{\mathrm{t}} & =\text { norm of capital capacity, and } \\
\mathrm{S}=\mathrm{S} / \mathrm{Y} & =\text { norm of saving. }
\end{array}
$$

As Harrod concluded, the policy of the government needs to stimulate economic growth or act to correct investment policy by balancing savings and investments, and minimizing the difference between guaranteed and natural economic growth. 


\section{Results and discussion}

The objective of macroeconomic policy is to accelerate economic growth and thus increase the population's incomes for improved standards of living for the people. Therefore, the measures for economic regulation should be about achieving high, stable rates of economic growth. Accelerated economic growth is possible only with sustained macroeconomic stability, which is the main condition for stimulating private investments. Therefore, a macroeconomic policy needs an element to achieve stability. In this respect, Uzbekistan's authorities should continue to pursue moderately tight monetary and fiscal policies, and maintain a flexible exchange rate policy.

In this section, we will attempt to develop an econometric model for stable economic growth in Uzbekistan. In constructing the econometric model, we will use economic statistical and mathematical modeling. The perspectives of stable economic growth in Uzbekistan can be divided into long, middle, and short terms. Moreover, the economic growth rate can be qualitative as well as quantitative. The reason for emphasizing this association is that the indicators of economic growth should always be in direct proportion to the real income of population and GDP per capita.

In addition, the competitiveness of the country's economy and absence of considerable difference between economies of developed nations under the conditions of globalization provides a highly positive estimation of the national economy.

In econometric modeling of the stable economic growth of Uzbekistan, we selected the following 13 main indicators:

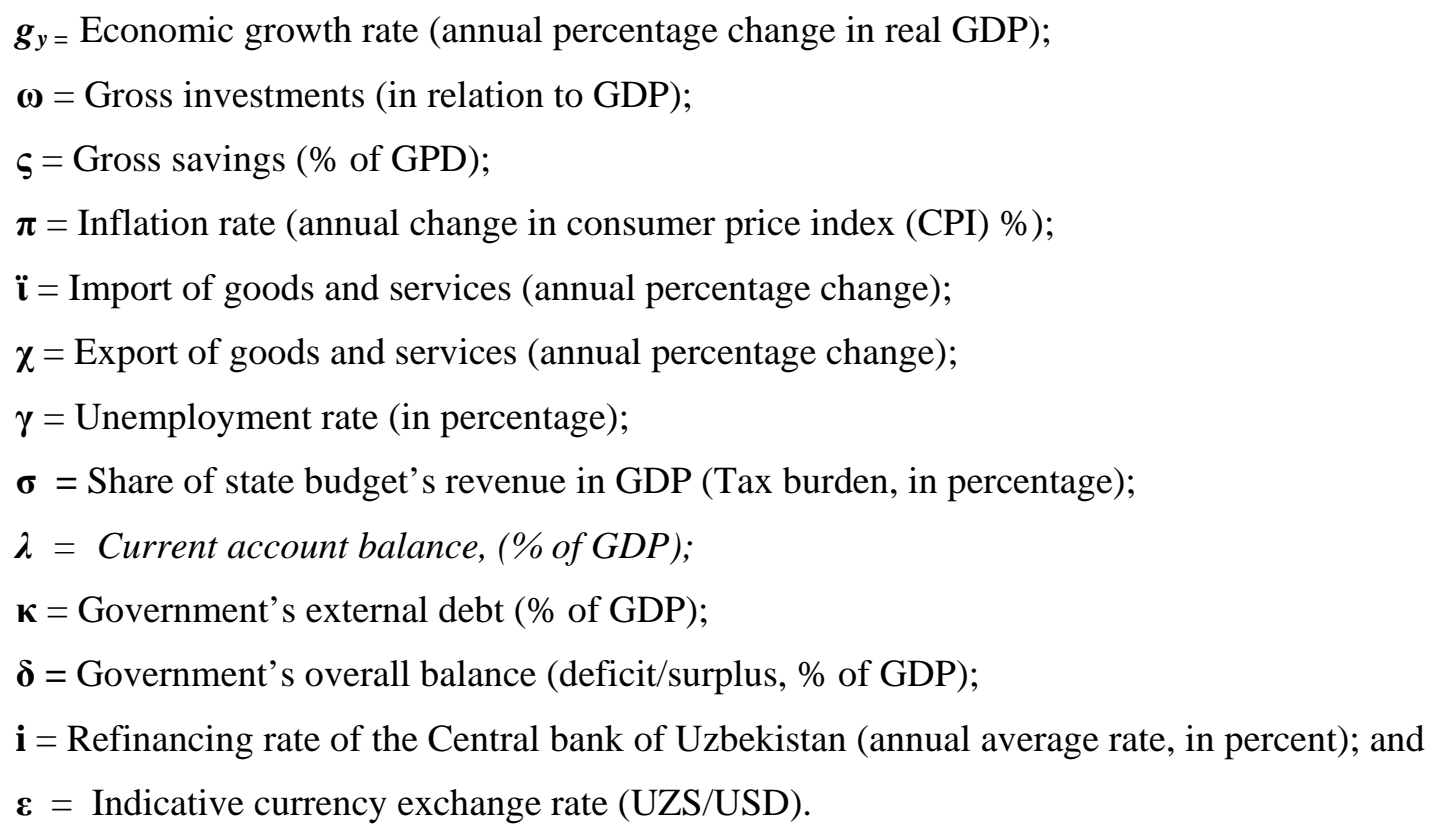

Regression analysis used the following data (Table 1).

Data in Table 1 were obtained from the official website of the International Monetary Fund (IMF), which differs to the information announced by official mass media of Uzbekistan. In other words, the real achievements attained by Uzbekistan are assumed to be wrongly estimated by the international financial institutions and foreign specialists.

There are two goals of using the listed indicators in this section.. Firstly, in spite of any evaluation made by the international financial institutions and foreign specialists, we aim to scientifically prove that Uzbekistan has strong opportunities for economic growth and high economic potential. Secondly, we intend to create an econometric model of economic growth in the form of a textbook for researchers and students. 
CBU I NTERNATI ONAL CONFERENCE ON I NNOVATION, TECHNOLOGY TRANSFER AND EDUCATION

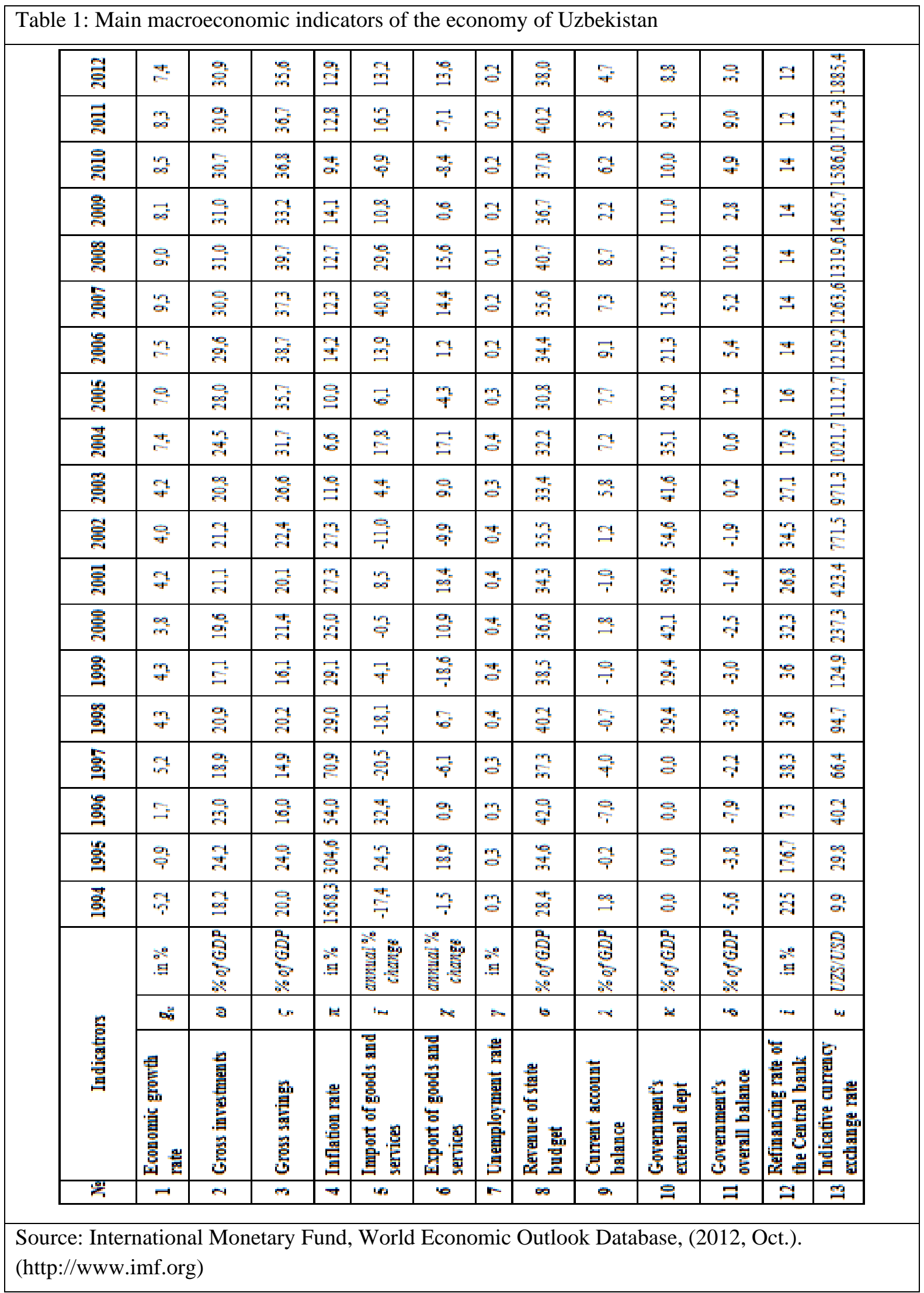

We used regression analysis to develop the econometric model for the stable economic growth of Uzbekistan. This process involves the following steps:

1. Find the correlation index of $\mathbf{g}_{\mathbf{y}}$ to other macroeconomic indicators 
2. A regression analysis of the correlation coefficient, $R^{2}$ of each macroeconomic indicator to $\mathbf{g}_{\mathbf{y}}$ (regression coefficient: $b_{1}$; the T-statistic: $t$ Stat; the least value of significance level: $P$-value; the highest and lowest limits of $95 \%$ probability from null hypothesis $\left(\mathrm{H}_{0}\right) \cdot \mathrm{H}_{0}: \beta_{1}=0 ; \mathrm{H}_{1}$ : $\beta_{1} \neq 0$ ).

If, during this examination, one, several or all of the indicators meet the conditions, such as indicator " $R$ ") is less than "one" but close to zero, the "t Stat" indicator is less than its critical positive value or more than critical negative value, the "P-value" indicator is more than its significance level (0.05) and if the highest and lowest values of $95 \%$ probability takes in "zero" value, the "zero" value will be true. In other words, it will be proved that there is no close correlation between the analyzed macroeconomic indicators and $\mathbf{g}_{\mathbf{y}}$, based on the following:

1. If any indicator has a close correlation with $\mathbf{g}_{\mathbf{y}}$ indicator, it will be tested last with the "Best Subsets Analysis" method of multivariable regression analysis;

2. To find a close relationship between macroeconomic indicators with the final test and $\mathbf{g}_{\mathbf{y}}$, the "null hypothesis" is accepted or rejected as stated in clause two above.

3. Those macroeconomic indicators, which have close a relationship to economic growth indicators, after running the test, are used in creating the econometric model of the economic growth.

4. The developed model is useful for forecasting the stable economic growth of Uzbekistan.

The computer software PHStat2 (add-in to Microsoft Office Excel) was used for the entire analytical process. The result of the analyses are shown in Figures 1 to 12 (see Appendix).

According to the results of the analyses, only seven of the 12 indicators closely correlated with $\boldsymbol{g}_{\boldsymbol{y}}$ (economic growth rate). They included, $\omega$ (gross investments), $\varsigma$ (gross savings), $\boldsymbol{\pi}$ (inflation rate), $\boldsymbol{\lambda}$ (current account balance), $\boldsymbol{\delta}$ (government's overall balance), $\boldsymbol{i}$ (refinancing rate of the Central Bank of Uzbekistan), and $\varepsilon$ (indicative currency exchange rate, UZS/USD).

The next step, the "Best Subsets Analysis", evaluated the close correlation between $\boldsymbol{g}_{\boldsymbol{y}}$ and the seven macroeconomic indicators.

The informational database from the regression analysis is given in Table 2.

According to the results of analysis, it was discovered that $\boldsymbol{g}_{\boldsymbol{y}}$ - economic growth rate has close correlation between $\boldsymbol{\pi}$-Inflation rate, $\boldsymbol{\lambda}$ - Current account balance and $\boldsymbol{\delta}$ - Government's overall balance.

\begin{tabular}{|c|c|c|c|c|c|c|c|c|}
\hline \multicolumn{2}{|l|}{ Table 2: “Best Subsets Analysis” regression analysis database } \\
\hline years & $\mathbf{g}_{\mathbf{y}}$ & $\mathbf{L n}(\boldsymbol{\omega})$ & $\mathbf{L n}(\boldsymbol{\varsigma})$ & $\mathbf{L n}(\boldsymbol{\pi})$ & $\boldsymbol{\lambda}$ & $\boldsymbol{\delta}$ & $\mathbf{L n}(\mathbf{i})$ & $\mathbf{L n}(\boldsymbol{\varepsilon})$ \\
\hline 1994 & -5.2 & 2.9 & 3.0 & 7.4 & 1.8 & -5.6 & 5.4 & 2.3 \\
\hline 1995 & -0.9 & 3.2 & 3.2 & 5.7 & -0.2 & -3.8 & 5.2 & 3.4 \\
\hline 1996 & 1.7 & 3.1 & 2.8 & 4.0 & -7.0 & -7.9 & 4.3 & 3.7 \\
\hline 1997 & 5.2 & 2.9 & 2.7 & 4.3 & -4.0 & -2.2 & 3.6 & 4.2 \\
\hline 1998 & 4.3 & 3.0 & 3.0 & 3.4 & -0.7 & -3.8 & 3.6 & 4.6 \\
\hline 1999 & 4.3 & 2.8 & 2.8 & 3.4 & -1.0 & -3.0 & 3.6 & 4.8 \\
\hline 2000 & 3.8 & 3.0 & 3.1 & 3.2 & 1.8 & -2.5 & 3.5 & 5.5 \\
\hline 2001 & 4.2 & 3.0 & 3.0 & 3.3 & -1.0 & -1.4 & 3.3 & 6.0 \\
\hline
\end{tabular}




\begin{tabular}{|c|c|c|c|c|c|c|c|c|}
\hline 2002 & 4.0 & 3.1 & 3.1 & 3.3 & 1.2 & -1.9 & 3.5 & 6.6 \\
\hline 2003 & 4.2 & 3.0 & 3.3 & 2.4 & 5.8 & 0.2 & 3.3 & 6.9 \\
\hline 2004 & 7.4 & 3.2 & 3.5 & 1.9 & 7.2 & 0.6 & 2.9 & 6.9 \\
\hline 2005 & 7.0 & 3.3 & 3.6 & 2.3 & 7.7 & 1.2 & 2.8 & 7.0 \\
\hline 2006 & 7.5 & 3.4 & 3.7 & 2.7 & 9.1 & 5.4 & 2.6 & 7.1 \\
\hline 2007 & 9.5 & 3.4 & 3.6 & 2.5 & 7.3 & 5.2 & 2.6 & 7.1 \\
\hline 2008 & 9.0 & 3.4 & 3.7 & 2.5 & 8.7 & 10.2 & 2.6 & 7.2 \\
\hline 2009 & 8.1 & 3.4 & 3.5 & 2.6 & 2.2 & 2.8 & 2.6 & 7.3 \\
\hline 2010 & 8.5 & 3.4 & 3.6 & 2.2 & 6.2 & 4.9 & 2.6 & 7.4 \\
\hline 2011 & 8.3 & 3.4 & 3.6 & 2.6 & 5.8 & 9.0 & 2.5 & 7.4 \\
\hline 2012 & 7.4 & 3.4 & 3.6 & 2.6 & 4.7 & 3.0 & 2.5 & 7.5 \\
\hline Source: Author & & & & & & \\
\hline
\end{tabular}

\begin{tabular}{|c|c|c|c|c|c|c|c|}
\hline Indicators & $\mathbf{n}$ & $\mathbf{R}^{2}$ & $\mathbf{b}_{1}$ & t Stat & P-value & $\begin{array}{l}\text { Lower } \\
95 \%\end{array}$ & $\begin{array}{l}\text { Upper } \\
95 \%\end{array}$ \\
\hline $\mathbf{g}_{\mathbf{y}}-$ convergence & \multirow{4}{*}{19} & \multirow{4}{*}{0.9428} & 11.8261 & 14.4620 & 0.0000 & 10.0831 & 13.5691 \\
\hline $\operatorname{Ln}(\pi)$ & & & -1.9198 & $\begin{array}{l}-8.6808 \\
\end{array}$ & 0.0000 & -2.3912 & -1.4484 \\
\hline$\lambda$ & & & -0.2062 & -2.4363 & 0.0278 & -0.3865 & -0.0258 \\
\hline$\delta$ & & & 0.4306 & 5.0237 & 0.0002 & 0.2479 & 0.6133 \\
\hline \multicolumn{3}{|c|}{ "Null Hypothesis": } & $\begin{array}{l}\mathrm{H}_{0}: \beta_{1}=0 \\
\mathrm{H}_{1}: \beta_{1} \neq 0\end{array}$ & \begin{tabular}{|c|} 
Greater than \\
positive critical \\
value \\
$(2.1098)$ and \\
less than \\
negative \\
critical value \\
$(-2.1098)$
\end{tabular} & \begin{tabular}{|} 
P-value is less \\
than \\
significance \\
level (0.05)
\end{tabular} & \multicolumn{2}{|c|}{$\begin{array}{l}\text { Confidence interval } \\
\text { not including zero }\end{array}$} \\
\hline
\end{tabular}

Source: Author

Conclusion: "Null hypothesis" was rejected. The $\boldsymbol{g}_{\boldsymbol{y}}$ (economic growth rate) significantly correlated with $\boldsymbol{\pi}$ (inflation rate), $\boldsymbol{\lambda}$ (current account balance), and $\boldsymbol{\delta}$ (government's overall balance).

According to the regression and the "Best Subsets Analysis", the ultimate model comprises following equation:

$$
g_{y}=-1.9198 * \operatorname{Ln}(\pi)-0.2062 * \lambda+0.4306 * \delta+11.8261
$$

The model of economic growth given above shows that there are three main macroeconomic indicators significantly correlating with the economic growth rate and these are the inflation rate $(\pi)$, the current account balance $(\lambda)$, and the government's overall balance $(\delta)$. This indicates that the appropriate treatment of these three indicators would positively affect the economic growth rate, and eventually the economic growth.

The reputable specialists of the international financial institutions report that, within 10 years, Uzbekistan needs to double its GDP, and maintain 8-10 percent growth each year to boost 
Uzbekistan's economy to the range of the developed world. This achievement is one of the major goals confronting Uzbekistan, today.

Based on our research analysis, we conclude that Uzbekistan has sufficient opportunity to make this a reality, as we scientifically explain.

For example, based on the regression analysis and the modelling for economic growth, Uzbekistan could achieve annual economic growth rate of $8-10$ percent, with an inflation rate of $6-7$ percent, an account balance to GDP of about $2-3$ percent, and the government's overall balance, compared to GDP, of just $1-2$ percent.

To be precise, if we submit our assumptions to the model mentioned above, such as inflation rate would comprise seven percent, current account balance compared to GDP three percent, and the government's overall balance to GDP one percent. This calculation will eventually show us the following economic growth rate:

$$
\begin{gathered}
g_{y}=-1.9198 * \operatorname{Ln}(\pi)-0.2062 * \lambda+0.4306 * \delta+11.8261= \\
=-1.9198 * \operatorname{Ln}(6)-0.2062 * 2+0.4306 * 1+11.8261=8.1 \%
\end{gathered}
$$

\section{Conclusion}

The only way to satisfy unlimited needs and wants, with limited economic resources and opportunities, is through economic growth. In addition, economic growth allows the development of social, political, military, and other spheres. Hence, since ancient times, the main attention in economic sciences pertains to analyzing the ways of economic growth.

On a macro scale, the growth of economy relates to enhancement of people's living conditions and standards, while economically raising the quality and quantity of production to a higher level. These changes are evident in the improvements in terms of the mass-production of goods and services, and positive changes in the quality and breadth of structure within a country.

It is important to mention that economic growth is not a natural process. Therefore, the attainment of economic growth demands the execution of an appropriate economic policy.

There are direct and indirect instruments of economic policy for a government to achieve economic growth. Direct instruments involve progress in innovational technologies, efficient usage of natural resources, leading investment policy and the support of high labor efficiencies. Indirect instruments of economic policy are the macroeconomic policy instruments, which include the state's tax budgetary (fiscal) policy, and monetary and credit (monetary) policies.

Nonetheless, it is important to use both direct and indirect instruments of the economic policy for economic growth, with the latter including the fiscal and monetary instruments, which work as catalysts for the growth of economy.

In this research, we attempted to theoretically develop the econometric model for the stable growth of Uzbekistan's economy. According to the results of the regression analysis, in the condition of Uzbekistan, three macroeconomic indicators: inflation rate $(\pi)$, current account balance $(\lambda)$, and the government's overall balance $(\delta)$, significantly correlated with the economic growth rate.

This means, Uzbekistan could achieve an ideal macroeconomic growth rate through the regulation and control of these three macroeconomic parameters.

Based on the above research analysis, we conclude that Uzbekistan has enough potential to turn the task mentioned into reality.

As Uzbekistan's goal is to soon achieve status within a range of developed countries of the world, we recommend the following to improve its macroeconomic policy: 
1. The mechanism of indirect taxation should be redirected from manufacturing process to consumption;

2. Organization of efficient usage of direct monetary policy instruments;

3. Increase the scale of joint companies, based on foreign investments;

4. Creation of new job opportunities, through accelerating and implementing localized programs;

5. Prevention of transferring financial resources in some areas to more developed regions through setting up private commercial banks and other financial institutions in these areas, so that the funds would be allocated and accumulated internally;

6. Widening the activity of special economic (industrial) zones and organize even more efficient usage of production potential in these areas.

We consider that the realization of the above suggestions would benefit the development of Uzbekistan and make it one of the most developed countries in Asia.

\section{References}

Appleyard, D., Field, F., \& Cobb, S. (2006). International economics. (5th ed.). Boston: McGraw-Hill/Irwin.

Chepurina, M. N. \& Kiselyov, E. A. (1999). The course of economic theory: Procedure Manual. Moscow: Moscow State. Institute of International Relations (4th ed.). Kirov: ASA.

Harrod, R.F. (1997). Theory of economic dynamics. Classical Keynesianism.

International Monetary Fund. (2012). World economic outlook database October 2012. Retrieved from http://www.imf.org.

Karimov, I. A. (2013). Our main goal - Big scaled reforms and firmly continuing the way of modernization. Tashkent, Uzbekistan.

Keynes, J. M. (1936). The general theory of employment, interest and money Retrieved: https://www.marxists.org/reference/subject/economics/keynes/.

Petty, W. (1679). A Treatise of Taxes and Contributions. London, Obadiah Blagrave, at the Sign of the Bear in St Paul's Corth-Door.

Phelps, E. (1966). Golden rules of economic growth. New York: Norton.

Smith, A. (1776). An inquiry into the nature and causes of the wealth of nations (1st ed.). London: W. Strahan.

Solow, R., (1956, February). A contribution to the theory of economic growth. Quarterly Journal of Economics.

Tojiboeva, D. (2003). Iqtisodiyot nazariyasi [Economic theory]. Tashkent, Uzbekistan: Sharq. 


\section{Appendix}

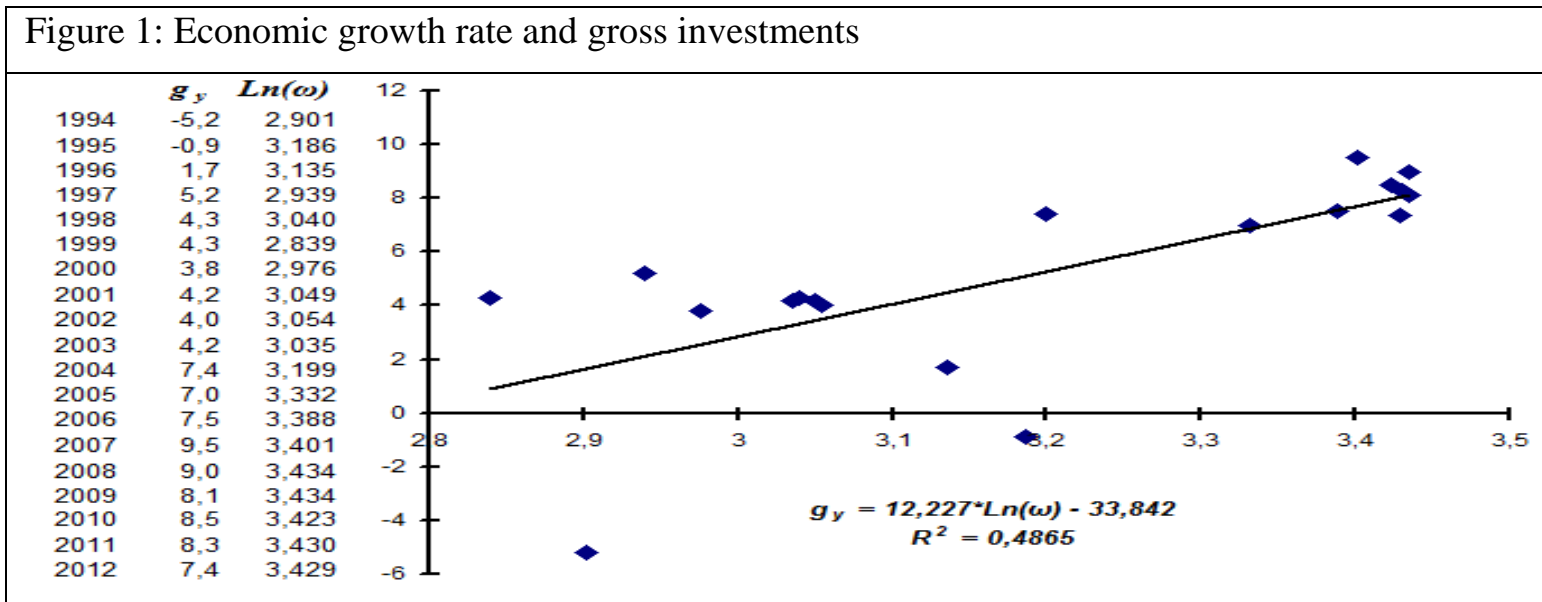

\begin{tabular}{|c|c|c|c|c|c|c|}
\hline \multicolumn{7}{|c|}{ Results of regression analysis: } \\
\hline $\mathbf{n}$ & $\mathbf{R}^{2}$ & $\mathbf{b}_{1}$ & t Stat & P-value & Lower 95\% & Upper 95\% \\
\hline 19 & 0.487 & 12.227 & 4.013 & 0.001 & 5.799 & 18.566 \\
\hline & esis": & $\begin{aligned} \mathrm{H}_{0}: & \beta_{1}=0 \mathrm{H}_{1}: \\
& \beta_{1} \neq 0\end{aligned}$ & $\begin{array}{l}\text { Greater than positive } \\
\text { critical value (2.1098) }\end{array}$ & $\begin{array}{c}\text { P-value is less than } \\
\text { significance level } \\
(0.05)\end{array}$ & \multicolumn{2}{|c|}{$\begin{array}{l}\text { Confidence interval not } \\
\text { including zero }\end{array}$} \\
\hline \multicolumn{3}{|c|}{ Conclusion: } & Reject $\mathrm{H}_{0}$ & \multicolumn{3}{|c|}{$\begin{array}{l}\text { There is a significant relationship between } \\
\text { economic growth rate and total investments. }\end{array}$} \\
\hline
\end{tabular}

Source: Author

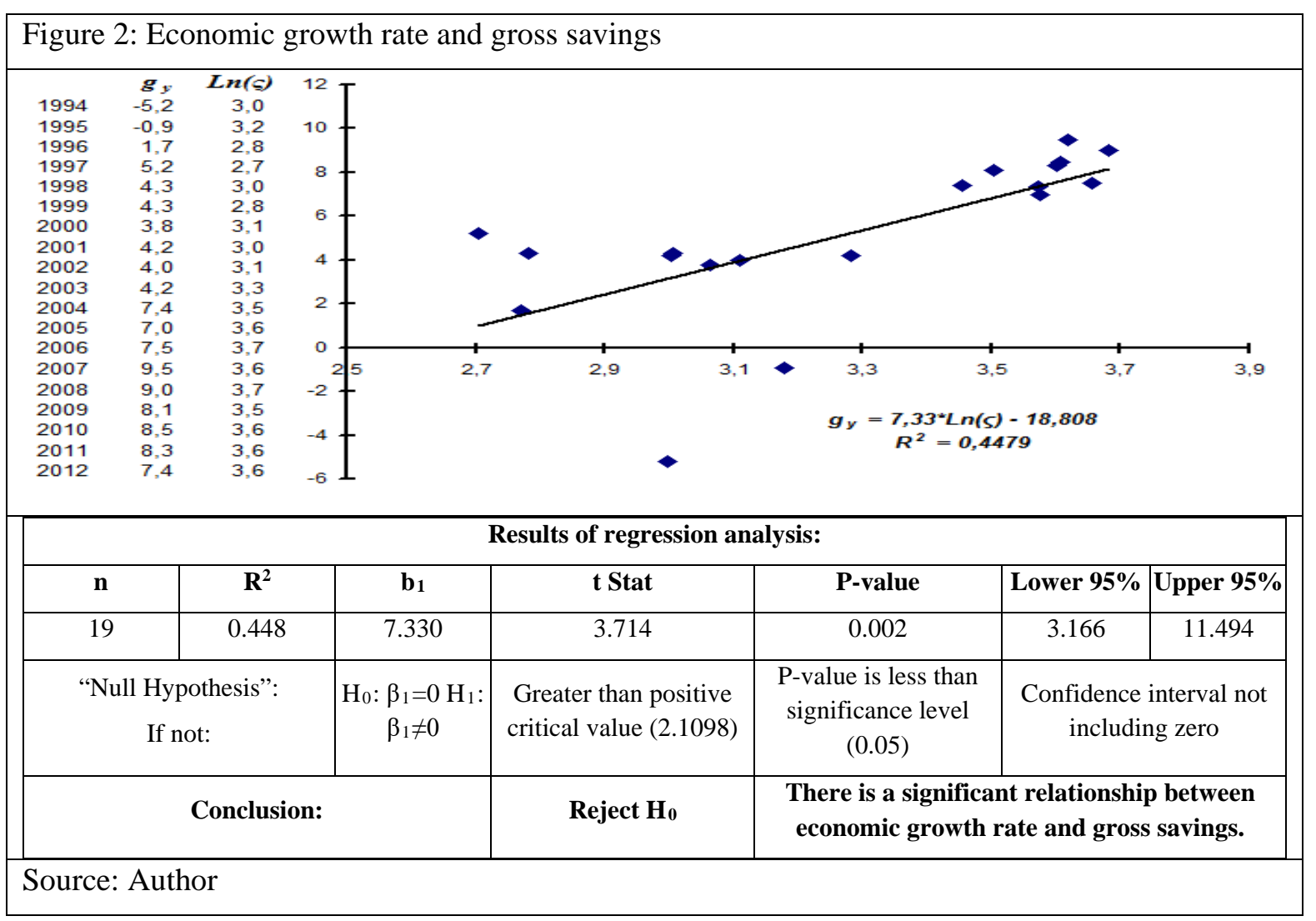




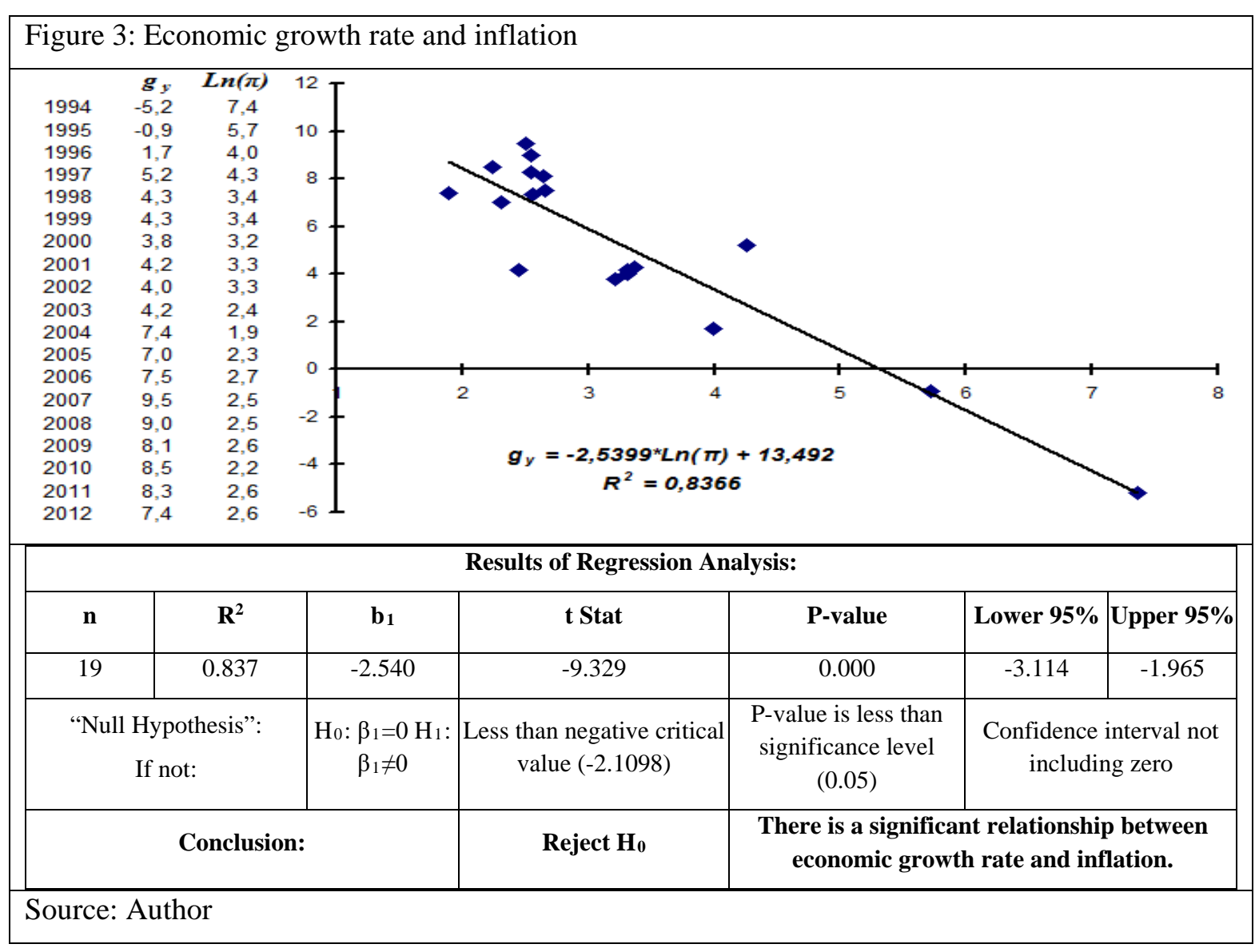

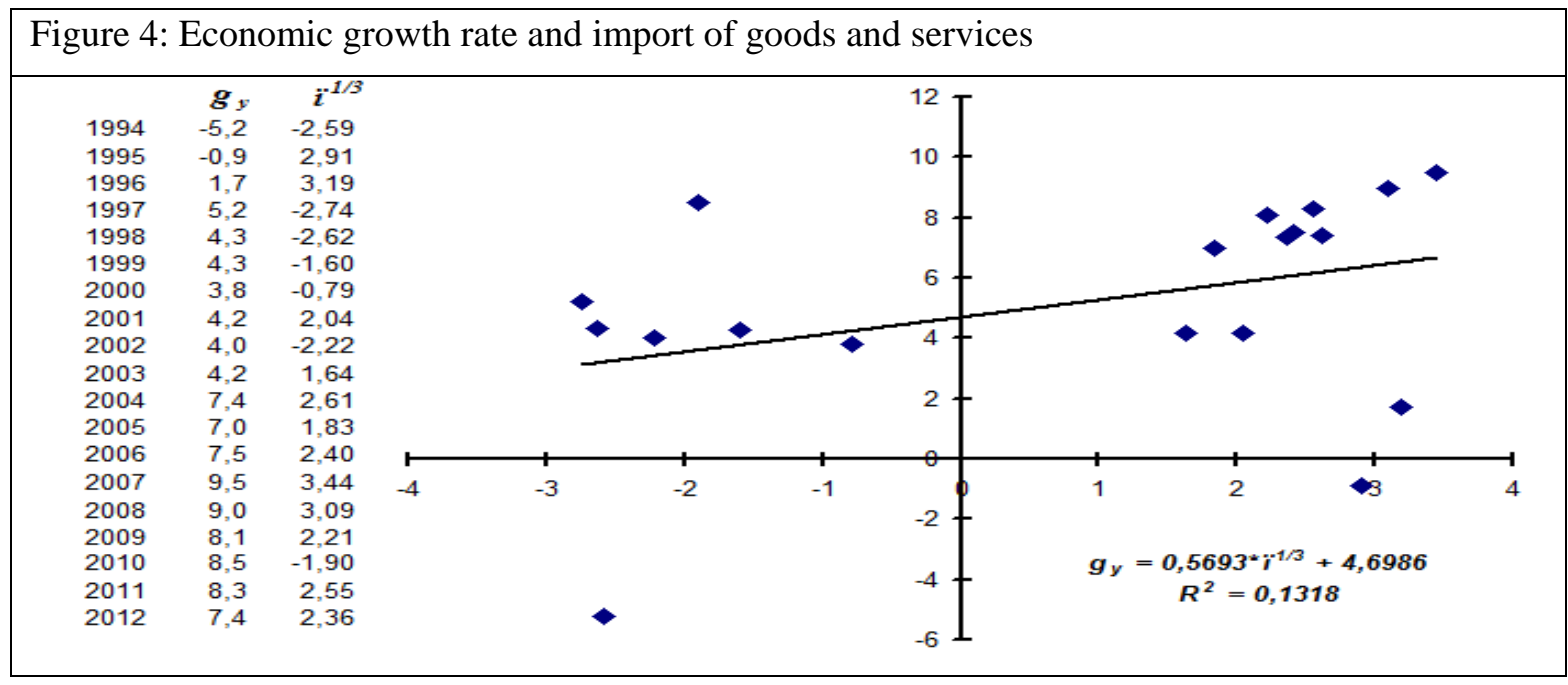




\begin{tabular}{|c|c|c|c|c|c|c|}
\hline \multicolumn{7}{|c|}{ Results of Regression Analysis: } \\
\hline $\mathbf{n}$ & $\mathbf{R}^{2}$ & $\mathbf{b}_{1}$ & t Stat & P-value & Lower 95\% & Upper 95\% \\
\hline 19 & 0.132 & 0.569 & 1.607 & 0.127 & -0.178 & 1.317 \\
\hline & hesis”: & $\begin{array}{c}\mathrm{H}_{0}: \beta_{1}=0 \mathrm{H}_{1}: \\
\beta_{1} \neq 0\end{array}$ & $\begin{array}{c}\text { Less than positive critical } \\
\text { value (2.1098) }\end{array}$ & $\begin{array}{l}\text { P-value is greater } \\
\text { than significance } \\
\text { level }(0.05)\end{array}$ & \multicolumn{2}{|c|}{$\begin{array}{l}\text { Confidence interval } \\
\text { including zero }\end{array}$} \\
\hline & \multicolumn{2}{|c|}{ Conclusion: } & Don't Reject $\mathrm{H}_{0}$ & \multicolumn{3}{|c|}{$\begin{array}{c}\text { There is no significant relationship between } \\
\text { economic growth rate and import of goods and } \\
\text { services }\end{array}$} \\
\hline \multicolumn{7}{|c|}{ Source: Author } \\
\hline
\end{tabular}

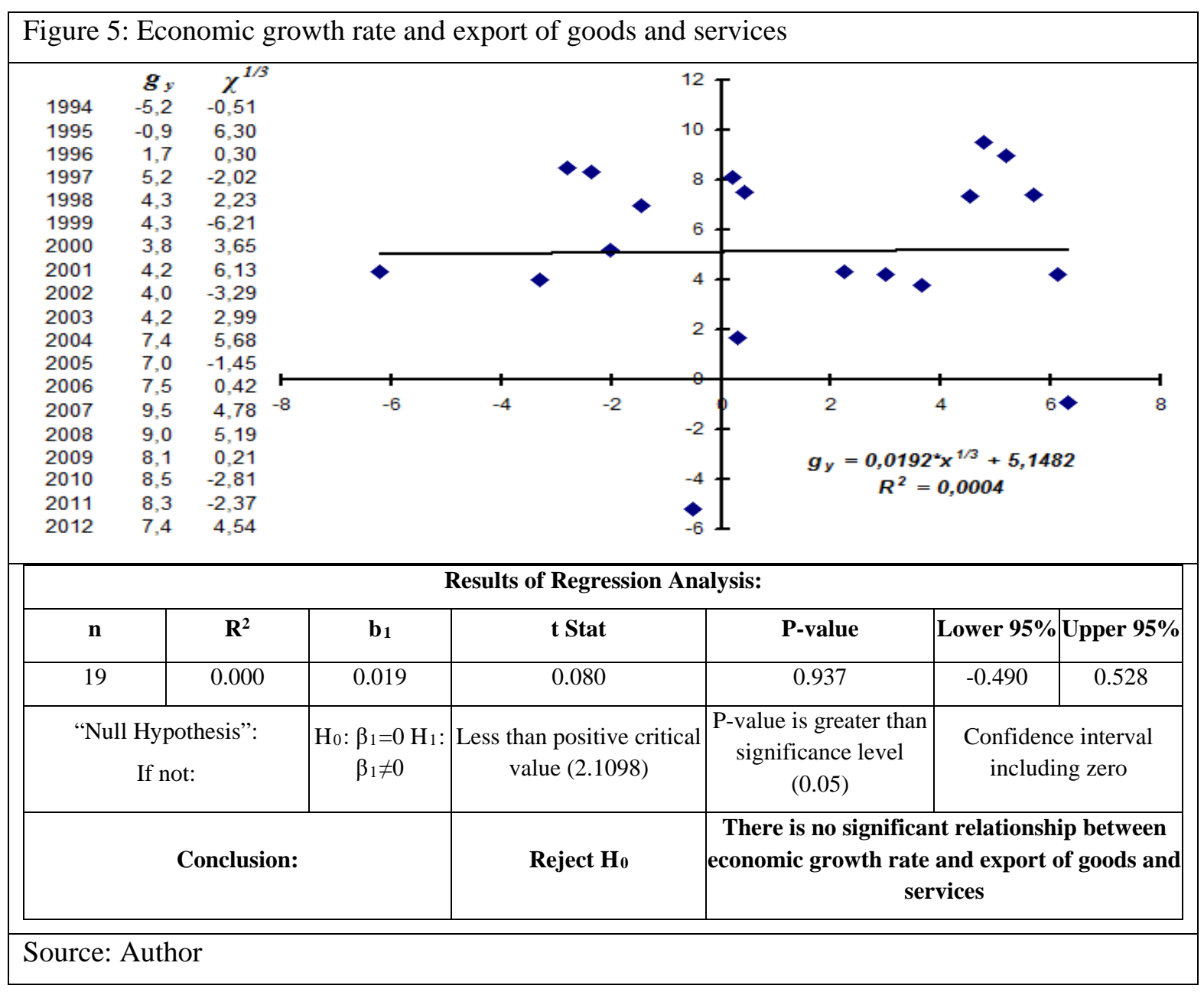




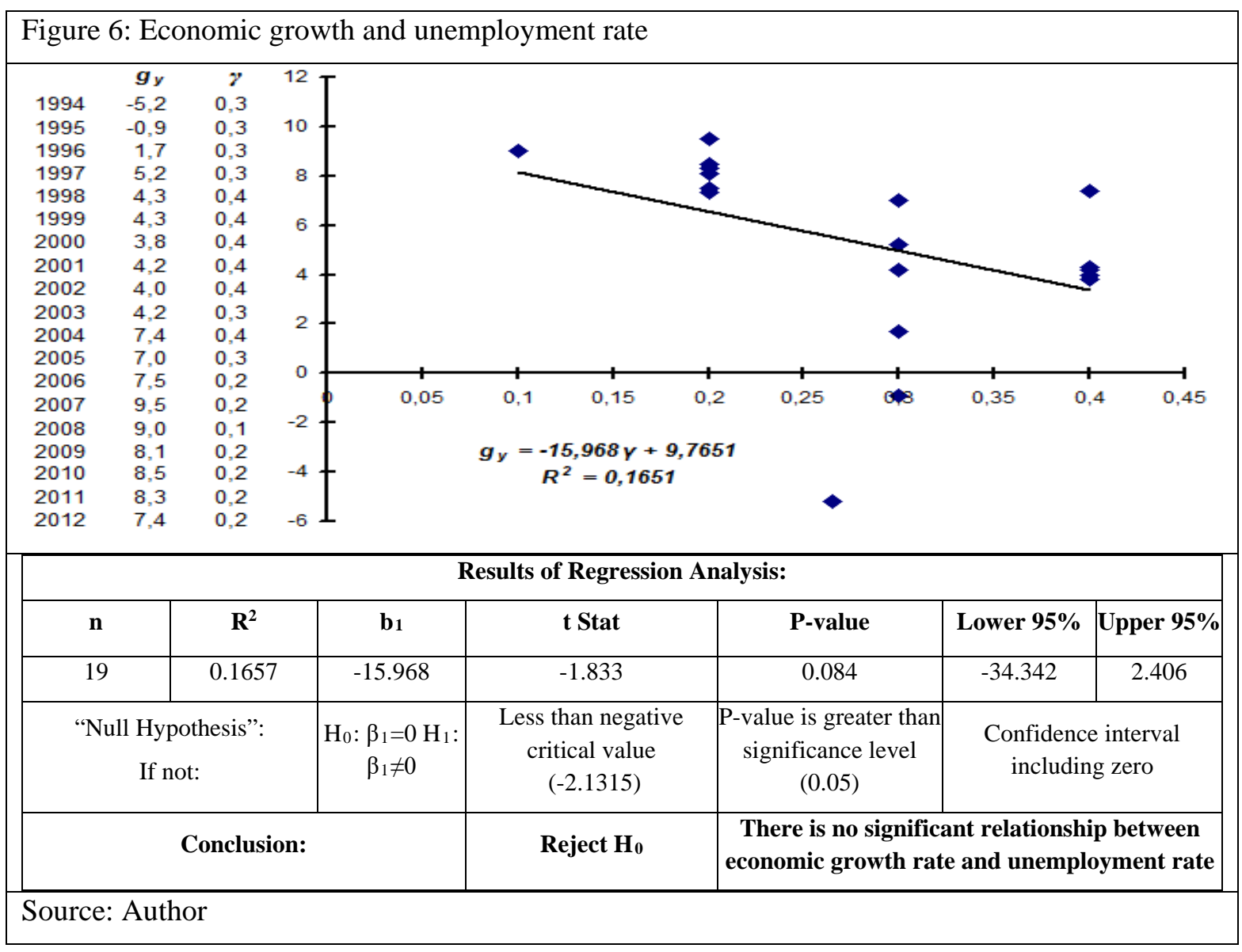

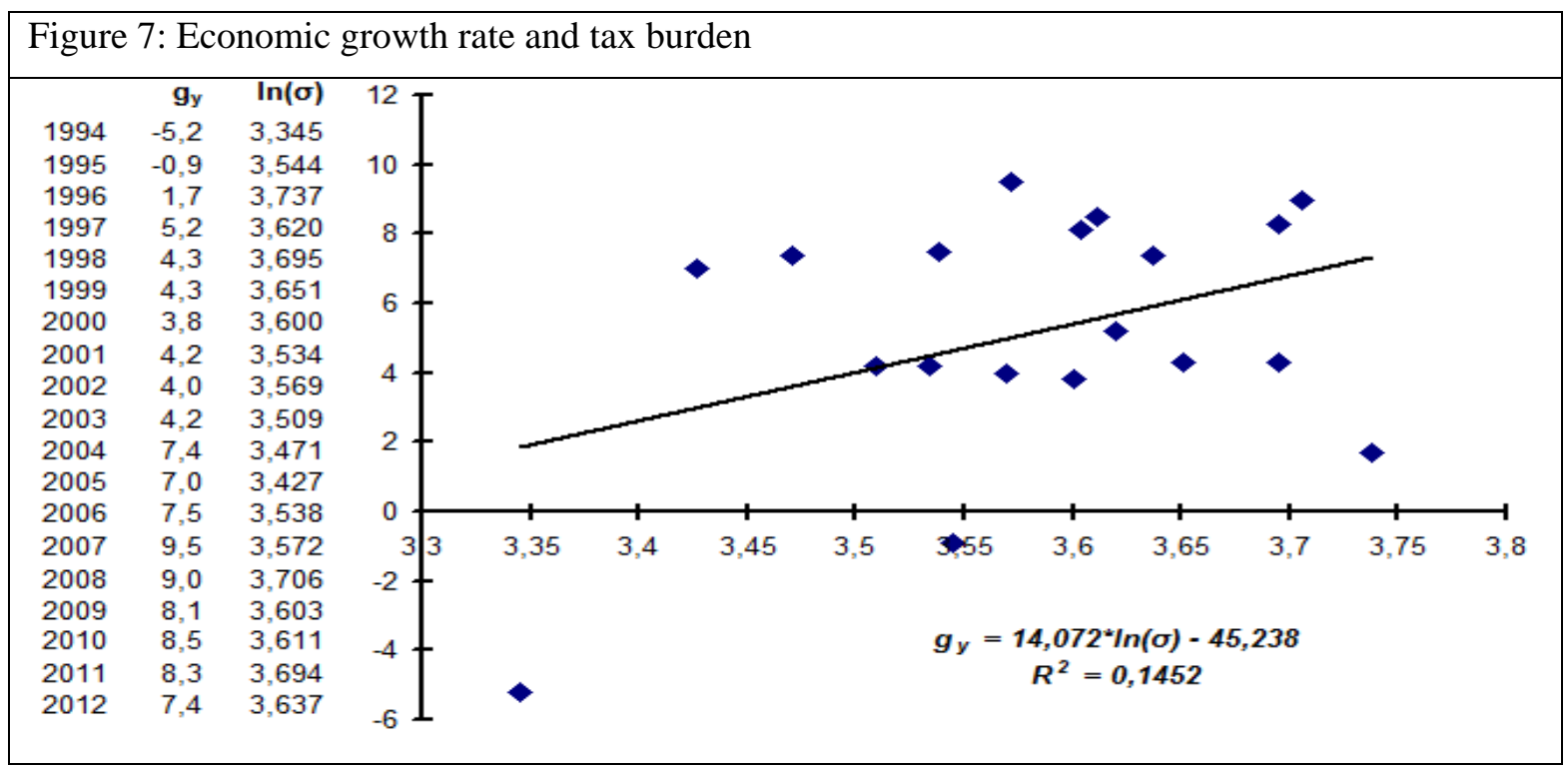




\begin{tabular}{|c|c|c|c|c|c|c|}
\hline \multicolumn{7}{|c|}{ Results of Regression Analysis: } \\
\hline $\mathbf{n}$ & $\mathbf{R}^{2}$ & $\mathbf{b}_{1}$ & t Stat & P-value & Lower 95\% & Upper 95\% \\
\hline 19 & 0.145 & 14.072 & 1.699 & 0.108 & -3.401 & 31.545 \\
\hline & hesis”: & $\begin{array}{c}\mathrm{H}_{0}: \beta_{1}=0 \mathrm{H}_{1}: \\
\beta_{1} \neq 0\end{array}$ & $\begin{array}{c}\text { Less than negative critical } \\
\text { value }(2.1098)\end{array}$ & $\begin{array}{l}\text { P-value is greater } \\
\text { than significance } \\
\text { level }(0.05)\end{array}$ & $\begin{array}{r}\text { Confidenc } \\
\text { includir }\end{array}$ & $\begin{array}{l}\text { ce interval } \\
\text { ng zero }\end{array}$ \\
\hline \multicolumn{3}{|c|}{ Conclusion: } & Reject $\mathrm{H}_{0}$ & \multicolumn{3}{|c|}{$\begin{array}{l}\text { There is no significant relationship between } \\
\text { economic growth rate and tax burden }\end{array}$} \\
\hline
\end{tabular}

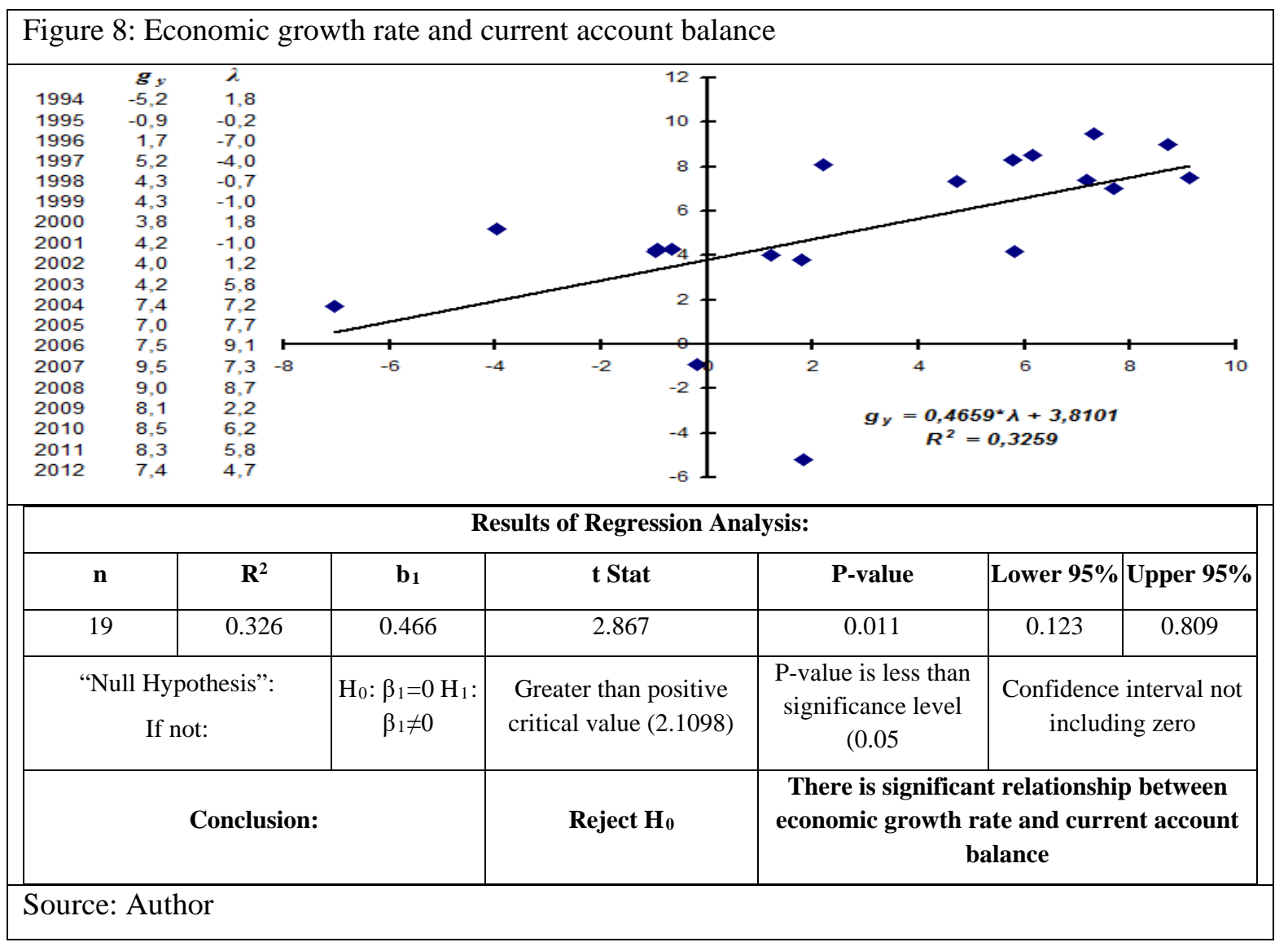




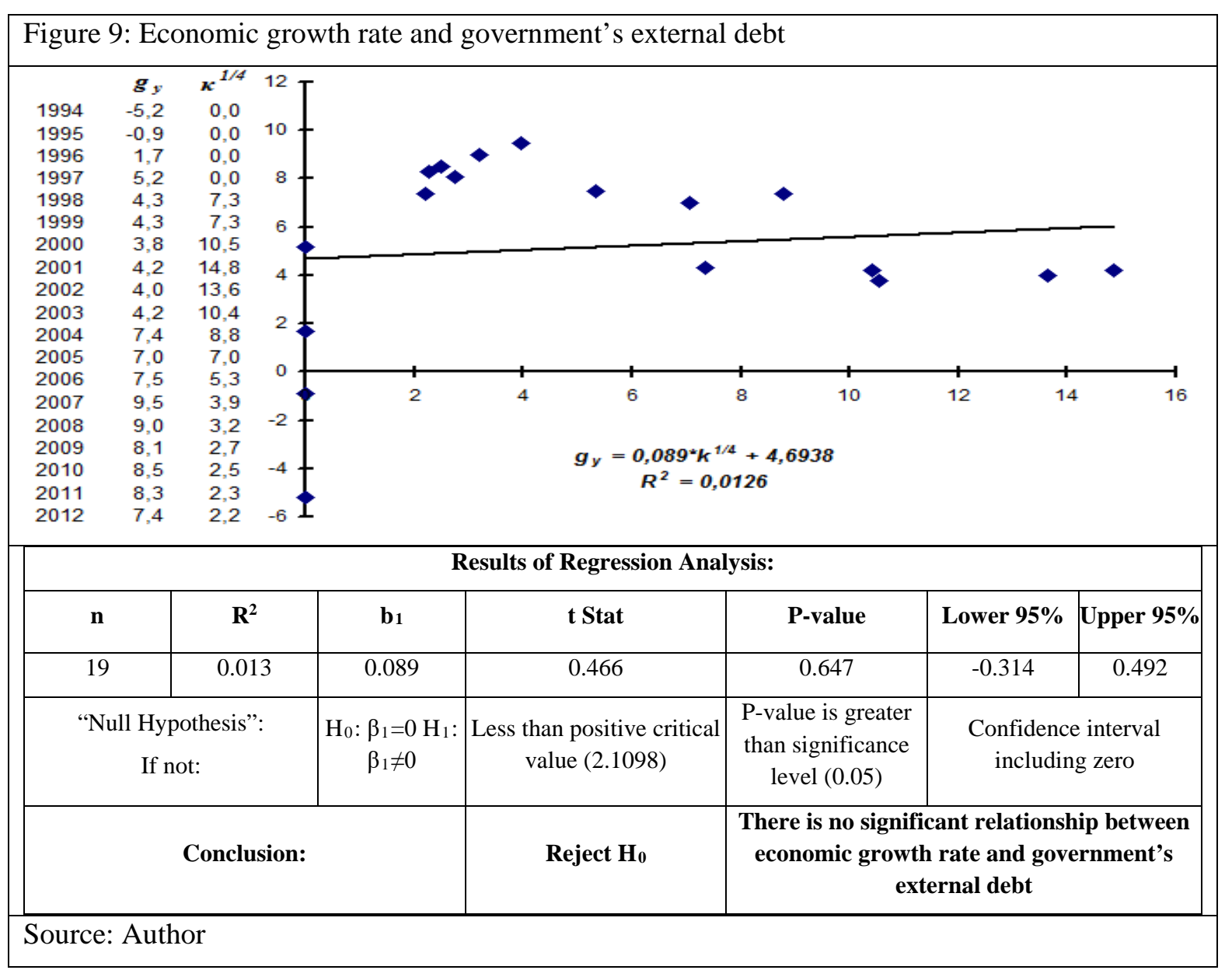

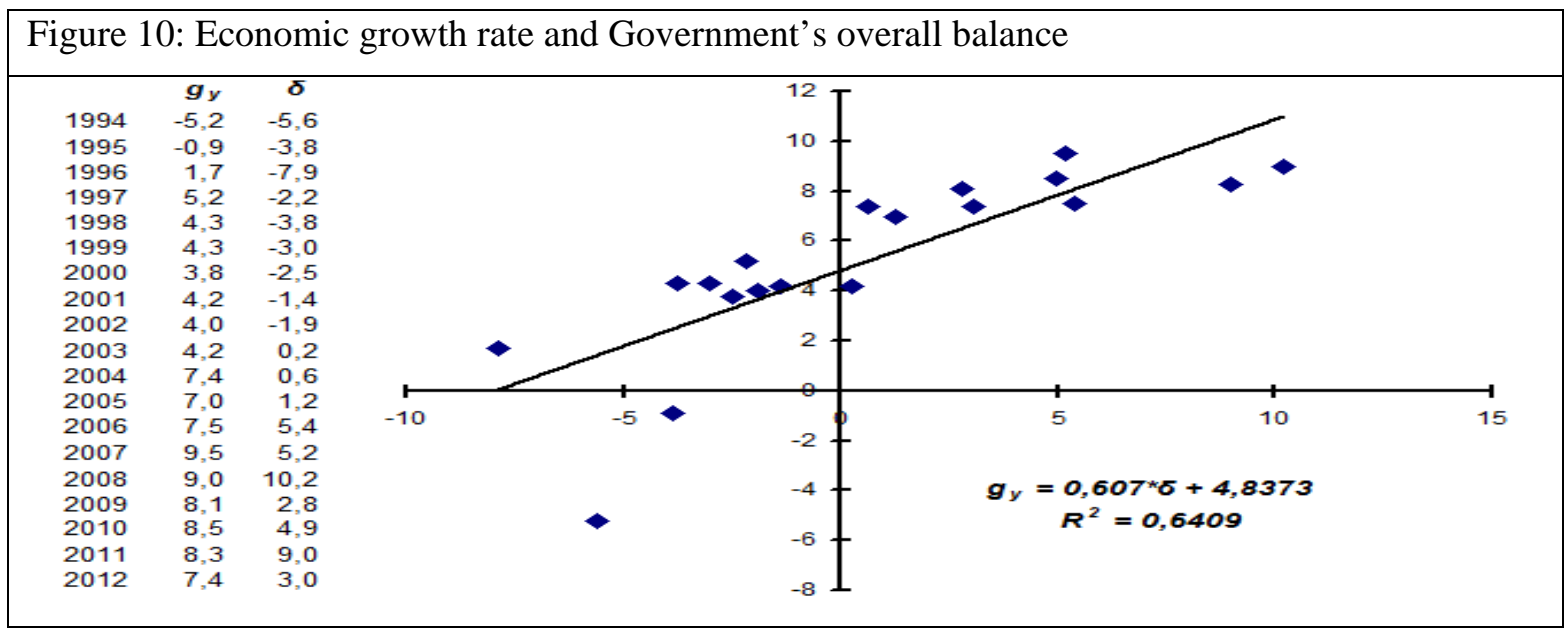




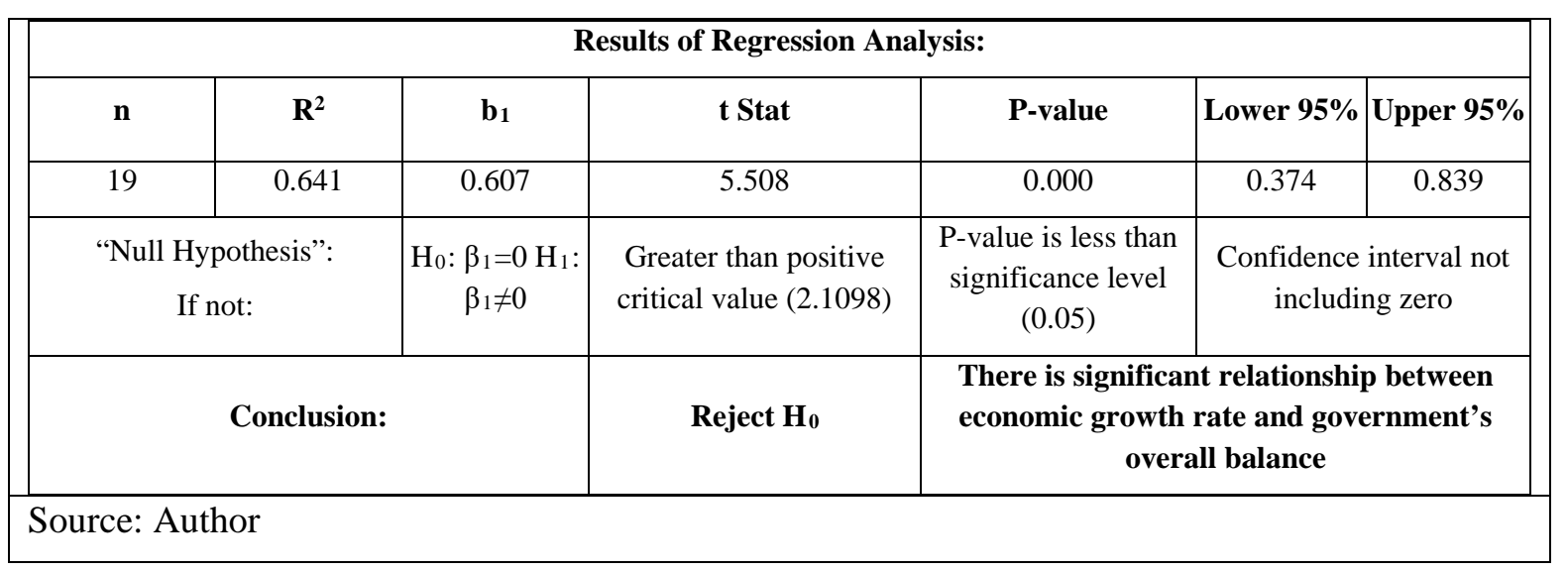

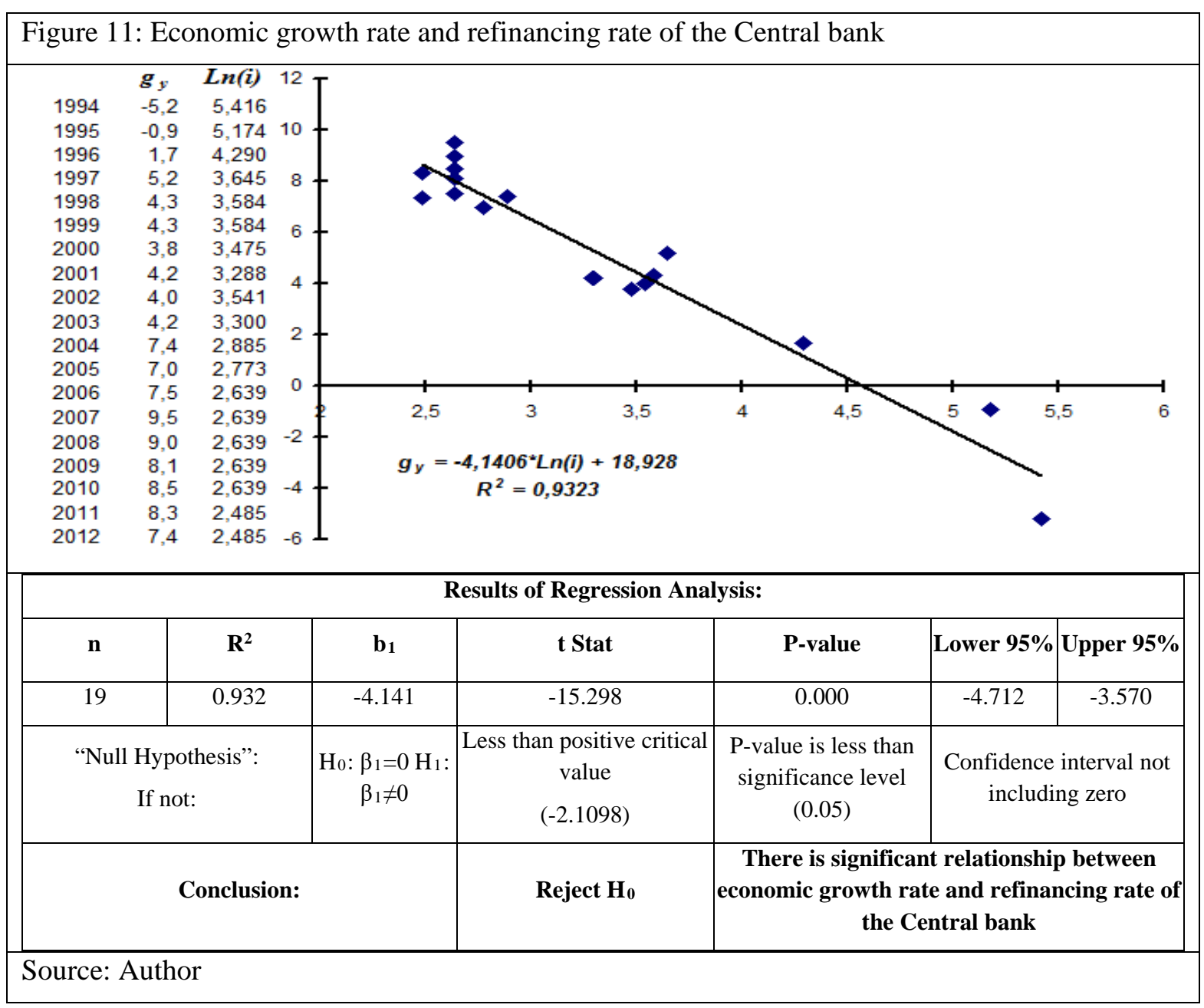




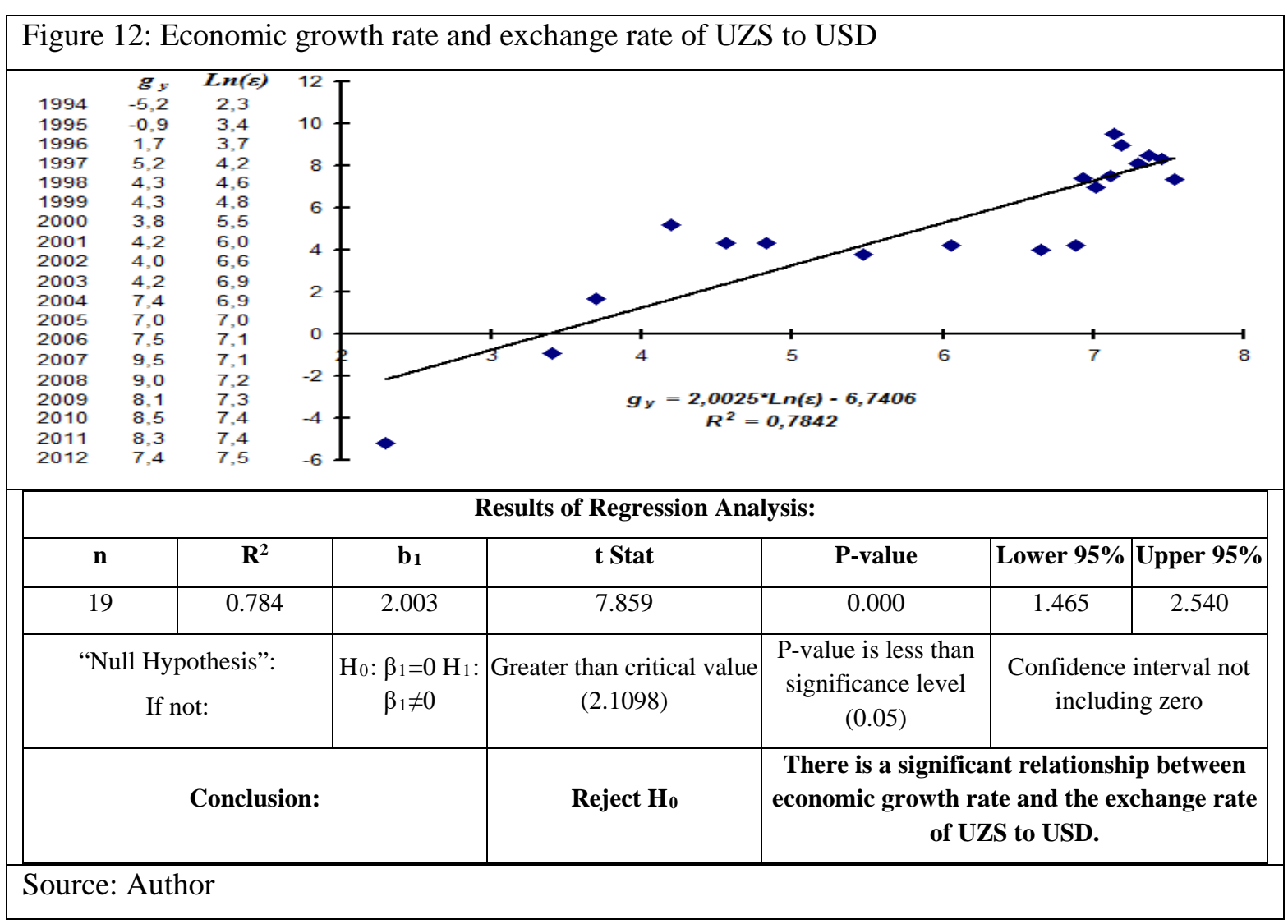

